\title{
PRZERZUCALNOŚĆ PODATKU OD TOWARÓW I USEUG NA RYNKU KSIĄŻEK
}

\section{WSTĘP}

Ferdynand Zweig w 1923 r. pisał, że: „Ustawodawca podatkowy musi znać prawa rządzące mechanizmem gospodarczym. Musi wiedzieć uprzednio, w jaki sposób i w którym kierunku rzucić ciężar podatkowy, by ciężar ten spadł w tym miejscu, które ustawodawca wybrał. Musi znać prawa rzutu ciężaru podatkowego, musi znać przebieg falowania, które pojawienie się nowego ciężaru wywoła na powierzchni życia gospodarczego"1. Współcześnie propozycje Zweiga dotyczące konieczności określenia skutków zmian przepisów podatkowych przed ich uchwaleniem wydają się idealistyczne. Obecnie władza publiczna w Polsce mniejszą wagę przywiązuje do konsekwencji wprowadzanego podatku dla funkcjonowania przedsiębiorców i gospodarstw domowych, a większą do poziomu dochodów, które z danego podatku moga być osiagnięte, choć i w tym zakresie określenie wszystkich skutków może budzić wątpliwości.

Podatek od wartości dodanej najczęściej jest klasyfikowany jako podatek konsumpcyjny, w przypadku którego zakłada się, że jego ciężar ponoszą konsumenci. Przedsiębiorcy zobowiązani są do zapłaty podatku, ale przyjmuje się, że spełniają wyłącznie funkcje podatnika w sensie formalnym. Podatnikiem w sensie materialnym zakłada się, że jest konsument, gdyż przedsiębiorcy, wkalkulowując podatek w cenę, żądają od konsumentów zapłaty kwoty netto powiększonej o podatek (tzw. przerzucalność pozorna). Przyjmuje się, że to konsumenci ponoszą ciężar podatku, czyli że sa podatnikami w sensie materialnym. Należy mieć jednak świadomość, że władza publiczna, ustanawiając podatki konsumpcyjne (w tym podatek od wartości dodanej), w sposób ograniczony decyduje o tym, kto poniesie ciężar podatku. O tym, jak rozłoży się ciężar podatku, przesądza przede wszystkim mechanizm rynkowy. W efekcie nałożenia podatku zmienia się równowaga, i to zarówno na rynku dóbr, jak i na rynku czynników produkcji. Tylko uwzględnienie zmian rynkowych wywołanych zmianami podatku pozwala odpowiedzieć na pytanie, na kogo przerzucony został podatek, kto ostatecznie poniósł ciężar podatku, czy mówiąc inaczej, jak przebiegała incydencja podatkowa.

O przerzucalności podatku można mówić wówczas, gdy zmiana podmiotu obciążonego podatkiem dokonuje się w drodze zmiany cen. Jeżeli nałożenie

${ }^{1}$ F. Zweig, Przerzucenie podatków, Krakowska Spółka Wydawnicza, Kraków 1923, s. 4. 
podatku wywołało wzrost cen towarów i usług sprzedawanych przez podmiot, na który podatek został nałożony, to można mówić o przerzucalności w przód. Jeżeli ciężar podatku obciąża dostawców podmiotu opodatkowanego, to można mówić o przerzucalności wstecz².

$\mathrm{Na}$ gruncie teorii incydencji podatkowej wskazuje się na „klasyczna trychotomię"3. Analizujac przerzucalność określonego podatku, badacze próbują odpowiedzieć na pytanie, czy obciąży on konsumentów, kapitał, czy pracę. Przerzucalność podatków jest przedmiotem zainteresowania naukowców na całym świecie. Badania nad przerzucalnością podatków pośrednich, do których można zakwalifikować podatek od towarów i usług, prowadzone sa w oparciu o tzw. modele równowagi cząstkowej lub dane empiryczne dotyczące określonych segmentów rynku.

W modelach równowagi czastkowej (w przeciwieństwie do modeli równowagi ogólnej) bada się konsekwencje nałożenia lub podwyższenia podatku wyłącznie dla określonego rynku. Przyjmuje się w tym przypadku założenie, że podatek nałożony na określone dobro nie wywołuje konsekwencji na innych rynkach, w tym na rynku czynników produkcji. W modelach równowagi cząstkowej bada się konsekwencje podatku jedynie na rynku, na którym opodatkowane dobro jest przedmiotem obrotu, i nie bierze się pod uwagę tego, w jaki sposób na przerzucalność podatku mogą wpływać pośrednicy.

W przypadku gdy przyjmuje się założenie, że analizowany rynek ma charakter rynku doskonale konkurencyjnego, wówczas incydencja podatkowa zależy od elastyczności cenowej popytu i podaży. Na rynkach oligopolistycznych wnioski dotyczące przerzucalności podatku są zależne od przyjętych założeń w szczególności dotyczących funkcji kosztów produkcji, kształtu krzywej popytu, a także od stopnia konkurencji w sektorze (liczba firm). Na podstawie modelu Cournota możliwe jest wyciągnięcie wniosku, że im silniejsza konkurencja w danym sektorze, tym ciężar podatku przerzucony na konsumentów bliższy będzie wartości podatku ${ }^{4}$. W modelu konkurencji monopolistycznej Avinasha K. Dixita i Josepha F. Stiglitza ${ }^{5}$, gdy opodatkowane dobra nie sa homogeniczne, podatek od wartości w całości przerzucany jest na konsumentów, ale w przeciwieństwie do podatków specyficznych (akcyz) nie można mówić o nadprzerzucalności (overshifting), czyli o wzroście cen, który przewyższałby wartość podatku ${ }^{6}$.

\footnotetext{
${ }^{2}$ Ibidem; Z. Jaśkiewicz, Przerzucalność podatków w polskim systemie podatkowym, w: Z. Jaśkiewicz (red.), Studia podatkowe i budżetowe, Wyd. UMK, Toruń 1964; A. Gomułowicz, Przerzucalność podatku obrotowego w PRL, Poznań, WN UAM, Poznań 1988; J. Sobiech, Podatki i opłaty publiczne, w: E. Denek, J. Sobiech, J. Wolniak, Finanse publiczne, WN PWN, Warszawa 2005; S. Owsiak, Finanse publiczne. Teoria i praktyka, WN PWN, Warszawa 2008.

${ }^{3}$ A. C. Harberger, The Incidence of the Corporation Income Tax Revisited, „National Tax Journal" 61, 2008, nr 2, s. 303-312.

${ }^{4}$ D. Fullerton, G. E. Metcalf, Tax Incidence, w: Handbook of Public Economics, t. 4, red. A. J. Auerbach, M. Feldstein, Elsavier, Amsterdam, 2002, s. 1787-1872; A Retrospective Evaluation of Elements of EU VAT System. Final Report 2011, TAXUD/2010/DE/328, FWC No. TAXUD/2010/CC/104, Project leader: Institute for Fiscal Studies.

${ }^{5}$ K. Dixit, J. E. Stiglitz, Monopolistic Competition and Optimum Product Diversity, „American Economic Review" 67, 1977, nr 3, s. 297-308.

${ }^{6}$ Wadą tego modelu jest to, że zakłada on, iż każdy towar jest konkurencyjny wobec wszystkich innych towarów.
} 
Pomimo że znaczenie problematyki incydencji podatkowej z perspektywy ekonomiki opodatkowania jest kluczowe, a badania modelowe nie prowadza do jednoznacznych wniosków, liczba badań empirycznych przeprowadzonych na świecie dotyczacych przerzucalności podatków jest stosunkowo niewielka. Za przykład badań empirycznych nad przerzucalnością podatków pośrednich w przód należy uznać analizę przeprowadzona przez Jamesa M. Poterbę ${ }^{7}$, dotycząca wpływu podatku od sprzedaży na ceny ubrań w kilku miastach Stanów Zjednoczonych Ameryki Północnej w latach 1925-1939 oraz 1947-1977. Analiza okresu powojennego sugeruje, że podatek od sprzedaży był w całości przerzucany na konsumentów, podczas gdy w okresie przedwojennym tylko 2/3 podatku były przerzucane na konsumentów. Podobną analizę przeprowadzili Timothy J. Besley i Harvey S. Rosen ${ }^{8}$. W tym przypadku przedmiotem badania było 12 rodzajów towarów w 155 miastach Stanów Zjednoczonych. Dane, na podstawie których prowadzono analizę, to dane kwartalne dotyczące lat 1975-1997. Autorzy zaobserwowali nadmierną przerzucalność (overshifting). Z przeprowadzonego badania wypływa również wniosek, że ceny bardzo szybko reagują na zmianę stawki podatku.

W opracowaniu Study on Reduced VAT ${ }^{9}$ przeanalizowane zostały konsekwencje znaczącej zmiany stawki podatku od wartości dodanej dla dziewięciu przypadków z rynku europejskiego obejmujących spadek stawki na książki w Szwecji o 19 punktów procentowych, wzrost stawki na obuwie we Włoszech o 4 punkty procentowe, wzrost stawki na czasopisma we Włoszech o 10 i późniejszy spadek stawki o 16 punktów procentowych, dwukrotny spadek stawki o 5 i 7 punktów procentowych na napoje w Portugalii, spadek stawki o 5 punktów procentowych na usługi restauracyjne w Portugalii i spadek stawki o 8 punktów procentowych na usługi fryzjerskie w Irlandii. Na podstawie tych badań można było stwierdzić, że wzrost stawki podatku powoduje bardziej niż proporcjonalna zmianę ceny, natomiast spadek stawki podatku powoduje mniej niż proporcjonalny spadek ceny. Gdy przedmiotem analizy były konsekwencje zmiany stawki o 1-2 punkty procentowe, wówczas obserwowane zależności były trudne do interpretacji.

Clément Carbonnier ${ }^{10}$ badał konsekwencje znaczacej zmiany stawki podatku od wartości dodanej na samochody, która miała miejsce we Francji 1 września 1987 r., i zmiany stawki podatku na usługi remontowe, która miała miejsce 1 września 1999 r. W przypadku samochodów ciężar podatku przerzucany na konsumentów został oszacowany na poziomie 57\%, podczas gdy w przypadku usług remontowych ciężar podatku ponoszony przez konsumentów wynosił $77 \%$. Autor zakres przerzucalności podatku wiąże z konkurencja na poszczególnych rynkach. W obu przypadkach Carbonnier ustalił, że poda-

7 J. M. Poterba, Retail Price Reactions to Changes in State and Local Sales Taxes, „National Tax Journal" 49, 1996, nr 2, s. 165-76.

8 T. J. Besley, H. S. Rosen, Sales Taxes and Prices: An Empirical Analysis, „National Tax Journal" 52, 1999, nr 2, s. 157-178.

${ }^{9}$ Study on Reduced VAT Applied to Goods and Services in the Member States of the European Union. Final report, Copenhagen Economics, Copenhagen 2007.

${ }^{10}$ C. Carbonnier, Who Pays Sales Taxes? Evidence from French VAT Reforms, 1987-1999, „Journal of Public Economics” 91, 2007, nr 5-6, s. 1219-1229. 
tek został przerzucony, zasadniczo rzecz ujmując, w okresie dwóch pierwszych miesięcy po przeprowadzeniu reformy.

Część badań empirycznych nad przerzucalnością dotyczy akcyz. Na przykład James Alm, Edward Sennoga, Mark Skidmore ${ }^{11}$ badali przerzucalność podatku akcyzowego na benzynę bezołowiową w Stanach Zjednoczonych. W tym celu analizowali miesięczne ceny benzyny dla 50 stanów w latach 1984-1999. Badanie dotyczyło przerzucalności podatku nałożonego na towar, którego cechy nie zmieniały się przez lata. Z badań wynika, że wzrost stawki podatku o 10\% prowadzi do przeciętnego wzrostu ceny detalicznej benzyny o 9,98\%. Należy jednak zauważyć, że w stanach uprzemysłowionych zaobserwowano pełną przerzucalność, podczas gdy w stanach rolniczych można mówić o niepełnej przerzucalności podatku na konsumentów. Ceny detaliczne bardziej reagują na wzrosty niż na spadki cen hurtowych. Do podobnych wniosków doszli także Severin Borenstein, Colin Cameron i Richard Shepard ${ }^{12}$, obserwujac zmiany cen detalicznych benzyny w reakcji na zmiany cen ropy naftowej.

Badania nad przerzucalnością podatków pośrednich dotyczą przede wszystkim przerzucalności w przód. Autorowi artykułu znana jest tylko jedna praca, której część dotyczy przerzucalności podatków pośrednich na pracowników. Alison R. Felix ${ }^{13}$ na podstawie danych z lat 1977-2005 dla Stanów Zjednoczonych badała, jaki wpływ na wysokość wynagrodzeń miał stanowy podatek dochodowy od korporacji, ale również stanowy podatek od sprzedaży. Z badań wynika, że stanowy podatek od sprzedaży w nieznacznym zakresie redukuje wynagrodzenia.

Wskazanie, który z kierunków przerzucenia podatków (w przód i wstecz) może być uznany za dominujący, stanowi w literaturze przedmiot dyskusji. Murray N. Rothbard ${ }^{14}$, przedstawiciel szkoły austriackiej, twierdzi, że ceny detaliczne ustalone przed wprowadzeniem powszechnego podatku od sprzedaży zostały ustalone na poziomie zapewniającym maksymalny przychód i nie ma miejsca na dodatkową podwyżkę cen w efekcie wzrostu stawki podatku. Oznacza to, że ciężar podatku będzie musiał zostać przerzucony wstecz. Spadek przychodów ze sprzedaży przekształci się w spadek dochodów kapitalistów oraz płac i rent pobieranych przez właścicieli czynników pierwotnych pracy i ziemi. Pogląd taki jest kwestionoway. William Barnet i Watter E. Block ${ }^{15}$ zarzucaja Rothbardowi w szczególności to, że jego analiza dotyczy tak krótkiego okresu, że w zasadzie nie są możliwe żadne dostosowania, oraz to, że prowadzi on analizę popytu w odniesieniu wyłącznie do zapasów, a nie do całego popytu. W rzeczywistości, zdaniem wspomnianych dwóch badaczy,

11 J. Alm, E. Sennoga, M. Skidmore, Perfect Competition, Urbanization, and Tax Incidence in the Retail Gasoline Market, „Economic Inquiry” 47, 2009, nr 1, s. 118-134.

12 S. Borenstein, C. Cameron, R. Shepard, Do Gasoline Prices Respond Asymmetrically to Crude Oil Price Changes?, „Quarterly Journal of Economics” 111, 1997, s. 306-339.

13 A. R. Felix, Do State Corporate Income Taxes Reduce Wages?, „Federal Reserve Bank of Kansas City Economic Review” 94, 2009, nr 2, s. 77-102.

${ }_{14}$ M. N. Rothbard, Ekonomia wolnego rynku, Ludwig von Mises Institute, Warszawa 2008.

15 W. Barnet, W. E. Block, On Rothbard on the Shifting and Incidence of a General Sales Tax: A Critique, „The Journal of Private Enterprise” 26(2), 2011, s. 117-126. 
będziemy obserwowali zarówno przerzucalność w przód, jak i przerzucalność wstecz.

Niniejszy artykuł wpisuje się w dyskusję dotyczącą przerzucalności powszechnego podatku obrotowego. Na podstawie danych empirycznych pochodzących z rynku książek w Polsce w latach 2003-2012 poszukiwana jest odpowiedź na pytanie o to, kto ponosi ciężar podatku od towarów i usług (w krótkim okresie), którego stawka wzrosła od 1 stycznia 2011 r.

Dane empiryczne wykorzystane w analizie pochodzą z Głównego Urzędu Statystycznego, Polskiej Izby Książki, Federacji Europejskich Wydawców (Federation of European Publishers) oraz bazy danych Amadeus w zakresie, w jakim dane dotyczą wydawców książek (NACE Rev.2 58.11) i drukarni (NACE Rev.2 18.12).

1 stycznia 2011 r. w Polsce nastapiła zmiana stawki podatku od towarów i usług na książki drukowane z $0 \%$ na 5\%. Zmiana stawki dokonana została na podstawie ustawy z 26 listopada 2010 r. o zmianie niektórych ustaw związanych z realizacją ustawy budżetowej (Dz. U. Nr 238, poz. 1578). Konieczność podwyższenia stawki na książki wynikała z dyrektywy Rady nr 2006/112/WE z 28 listopada 2006 r. w sprawie wspólnego systemu podatku od wartości dodanej (Dz. Urz. UE L 347 z 11 grudnia 2006, s. 1, ze zm.), która stanowi, że państwa członkowskie maja prawo do stosowania dwóch obniżonych stawek nie niższych niż 5\% wyłącznie w odniesieniu do dostaw towarów i świadczenia usług określonych w załączniku III. W pozycji 6 tego załącznika wymieniono dostawę książek. Możliwość stosowania stawki na poziomie $0 \%$ do końca 31 grudnia 2010 r. wynikała z derogacji, która Polska uzyskała od Komisji Europejskiej w momencie wejścia do Unii i w efekcie późniejszych negocjacji.

W rozporządzeniu Ministra Finansów z 22 grudnia 2010 r. w sprawie wykonania niektórych przepisów ustawy o podatku od towarów i usług (Dz. U. Nr 246, poz. 1649) została przewidziana możliwość zastosowania stawki 0\% do końca kwietnia 2011 r. Warunkiem zastosowania stawki 0\% w odniesieniu do dostawy książek było przekazanie ich do dystrybucji przed 1 stycznia $2011 \mathrm{r}$. lub ujęcie ich w spisie z natury sporządzonym na dzień 31 grudnia $2010 \mathrm{r}$. Możliwość zastosowania stawki 0\% przez wydawców w 2011 r. była ograniczona, gdyż po pierwsze, ustawa wprowadzająca stawkę 5\% została przyjęta 26 listopada 2010 r. i ukazała się w „Dzienniku Ustaw” w połowie grudnia 2010 r., czyli vacatio legis była krótka, a po drugie, jeżeli konsumenci mieli skorzystać ze stawki 0\% w okresie przejściowym, książki musiały trafić do dystrybutorów przed końcem 2010 r.

Stosowanie obniżonej stawki podatku od wartości dodanej na książki wynika z charakteru tego dobra. Książka uznawana jest za towar, którego konsumpcja jest pożądana (merit good). Władza publiczna dąży do tego, by o dostępie do edukacji (w tym do książek) nie decydował wyłącznie poziom dochodów gospodarstw domowych i mechanizm rynkowy. Formy wsparcia czytelnictwa moga być różne, a za jedna z nich może być uznane stosowanie obniżonych stawek podatku od towarów i usług na książki. Skuteczność tego narzędzia wsparcia czytelnictwa nie jest jednak oczywista, wymaga znajomości rynku książki. 


\section{RYNEK KSIĄŻKI}

Według badań prowadzonych przez Bibliotekę Narodową odsetek osób czytających co najmniej jedną książkę rocznie w okresie ostatnich dziesięciu lat spadł z 56\% w roku 2002 r. do 39\% w 2012. Zmiany te sa tłumaczone zmianami $\mathrm{w}$ sposobie spędzania czasu wolnego, zmianami cywilizacyjnymi zachodzącymi w sposobie percepcji słowa pisanego.

Tabela 1

Odsetek osób czytających co najmniej jedną książkę rocznie w Polsce w latach 2002-2012

\begin{tabular}{|c|c|c|c|c|c|c|}
\hline Rok & $\mathbf{2 0 0 2}$ & $\mathbf{2 0 0 4}$ & $\mathbf{2 0 0 6}$ & $\mathbf{2 0 0 8}$ & $\mathbf{2 0 1 0}$ & $\mathbf{2 0 1 2}$ \\
\hline $\begin{array}{l}\text { Odsetek osób } \\
\text { czytających książki }\end{array}$ & $56 \%$ & $58 \%$ & $50 \%$ & $38 \%$ & $44 \%$ & $39 \%$ \\
\hline
\end{tabular}

Źródło: Biblioteka Narodowa, http://www.bn.org.pl/download/document/1362741578.pdf.

W 2012 r. w Polsce było zarejestrowanych blisko 38000 wydawnictw. Wydawnictw aktywnych działało nie więcej niż 2000 do 2500. Spośród nich trzysta największych generowało 98\% przychodów wszystkich wydawnictw.

Tabela 2

Wartość przychodów ze sprzedaży wydawców książek w Polsce w latach 2003-2012 [w mln zł]

\begin{tabular}{|c|c|c|c|c|c|c|c|c|c|c|}
\hline Rok & $\mathbf{2 0 0 3}$ & $\mathbf{2 0 0 4}$ & $\mathbf{2 0 0 5}$ & $\mathbf{2 0 0 6}$ & $\mathbf{2 0 0 7}$ & $\mathbf{2 0 0 8}$ & $\mathbf{2 0 0 9}$ & $\mathbf{2 0 1 0}$ & $\mathbf{2 0 1 1}$ & $\mathbf{2 0 1 2}$ \\
\hline $\begin{array}{l}\text { Wartość sprzedaży } \\
\text { wydawców książek }\end{array}$ & 2090 & 2210 & 2460 & 2380 & 2600 & 2910 & 2860 & 2940 & 2710 & 2670 \\
\hline
\end{tabular}

Źródło: Badanie rynku książki w Polsce. Raport Polskiej Izby Książki, http://www.pik.org.pl/upload/files/ Rynek_ksiazki.Raport_PIK_7-11-2013_final.docx.

Wartość przychodów ze sprzedaży wydawców w 2012 r. wynosiła 2,67 mld zł. Wzrost wartości sprzedaży, zasadniczo rzecz ujmując, miał miejsce do $2010 \mathrm{r}$. włącznie. Ostatnie dwa analizowane lata oznaczaja spadek przychodów ze sprzedaży wydawców.

$\mathrm{Z}$ perspektywy dalszych analiz ma również znaczenie fakt, że nie ma możliwości przygotowania nowej książki z dnia na dzień. Proces wydawniczy trwa co najmniej kilka miesięcy, zanim książka trafi do druku.

Największy udział w strukturze sprzedawanych książek w 2012 r. miały książki naukowe i fachowe $(36,5 \%)$ oraz podręczniki szkole $(31,5 \%)$. Udział obu tych kategorii wzrósł znacząco w ostatnich latach. Zwraca uwage fakt, że popyt na dwa wspomniane typy książek może być uznany za stosunkowo sztywny, niezależny od ceny. 
Znajomość podstawowych faktów dotyczących rynku książki ułatwia zrozumienie zjawisk zachodzących na tym rynku. Dalsza analiza będzie dotyczyła przerzucalności zarówno w przód, jaki i wstecz.

\section{PRZERZUCALNOŚĆ PODATKU OD TOWARÓW I USŁUG NA CZYTELNIKA}

O przerzucalności w przód można mówić wówczas, gdy w reakcji na zmianę stawki podatku wzrosła cena, którą muszą zapłacić konsumenci. Analiza przerzucalność podatku od towarów i usług wymaga ustalenia, jak zmieniła się cena książek w momencie zmiany stawki podatku, a przede wszystkim czy zmiana ceny może być uznana za bezpośrednią konsekwencję zmiany stawki, czy też wynika z innych czynników, takich jak np. inflacja. Należy przy tym podkreślić, że z dotychczas przeprowadzonych badań wynika, że do przerzucalności podatku dochodzi w krótkim okresie po jego podwyżce. Dlatego dalsza analiza będzie się koncentrowała na porównaniach 2010 i 2011 r.

Tabela 3

Przeciętna cena detaliczna książki w Polsce w latach 2003-2012 [w zł]

\begin{tabular}{|c|c|c|c|c|c|c|c|c|c|c|}
\hline Rok & $\mathbf{2 0 0 3}$ & $\mathbf{2 0 0 4}$ & $\mathbf{2 0 0 5}$ & $\mathbf{2 0 0 6}$ & $\mathbf{2 0 0 7}$ & $\mathbf{2 0 0 8}$ & $\mathbf{2 0 0 9}$ & $\mathbf{2 0 1 0}$ & $\mathbf{2 0 1 1}$ & $\mathbf{2 0 1 2}$ \\
\hline $\begin{array}{l}\text { Średnia cena } \\
\text { detaliczna ksiażki }\end{array}$ & 29,1 & 29,2 & 29,3 & 30,2 & 30,5 & 31,9 & 32,5 & 34,3 & 37,8 & 38,7 \\
\hline
\end{tabular}

Źródło: Rynek książki w Polsce 2013, Biblioteka Analiz, za: http://www.instytutksiazki.pl/upload/Files/ RYNEK_KSIKI_W_POLSCE_2013.pdf.

Przeciętna cena książki w roku 2011 w porównaniu z 2010 wzrosła o 10,2\%. W 2011 r. inflacja wynosiła 4,3\%. Wzrost ceny książek może być zatem wyjaśniony częściowo wzrostem inflacji, a częściowo może wynikać ze zmiany stawki podatku. Jeżeli przyjmie się założenie, że na zmianę ceny książek miały wpływ dwa wspomniane czynniki, to efektem zmiany stawki o 5 p.p. byłby wzrost cen o 5,7\%. Na tej podstawie możliwe byłoby stwierdzenie, że miała miejsce nadprzerzucalność (overshifting).

Aby potwierdzić zależności pomiędzy ceną detaliczną książki a inflacją oraz stawką podatku od towarów i usług, można stworzyć model ekonometryczny, w którym za zmienną zależną zostanie uznany logarytm ceny detalicznej książki, a za zmienne objaśniajace zostana przyjęte inflacja i stawka podatku od towarów i usług. W modelu takim jedyną istotna statystycznie zmienną objaśniająca jest stawka podatku z $p$-value na poziomie 0,0073 . $\mathrm{W}$ modelu tym współczynnik $p$-value dla zmiennej inflacja wynosi 0,2714. Jeżeli do modelu $\mathrm{w}$ miejsce inflacji podstawiona zostanie zmienna cza- 
sowa, to jakość modelu znacząco się poprawi. Skorygowany współczynnik dopasowania poprawionego modelu wynoszacy 0,973104 może być uznany za wysoki ${ }^{16}$. Poniżej przedstawiony został model obrazujący wspomniane zależności.

\section{Model 1}

Logarytm ceny detalicznej książki objaśniany zmienną czasową i stawką podatku od towarów i usług na podstawie danych z lat 2003-2012 według metody najmniejszych kwadratów

\begin{tabular}{lcccc} 
& Wspótczynnik & Btad stand. & $t$-Studenta & Wartość $p$ \\
Const & 3,32384 & 0,0133705 & 248,5954 & $<0,00001$ \\
Zmienna czasowa & 0,0232315 & 0,00264451 & 8,7848 & 0,00005 \\
stawka podatku & 0,099535 & 0,0189895 & 5,2416 & 0,00120 \\
Wsp. determ. R-kwadrat & \multicolumn{2}{c}{0,979081} & Skorygowany R-kwadrat & 0,973104 \\
$\mathrm{~F}(2,7)$ & \multicolumn{2}{c}{163,8083} & Wartość p dla testu F & $1,32 \mathrm{e}-06$
\end{tabular}

W modelu tym zmienna objaśniająca ,stawka VAT” jest istotna statystycznie z $p$-value wynoszącym 0,00120. Współczynnik przy tej zmiennej $(0,099535)$ można zinterpretować w ten sposób, że wzrost stawki z 0\% do 5\% powoduje wzrost ceny o 10,47\%. Taki wzrost ceny sugerowałby nadmierną przerzucalność (overshifting) podatku na konsumentów, większą nawet, niż to wynikało z prostej analizy zmiany cen, inflacji oraz zmiany stawki podatku w roku 2011 w porównaniu z 2010.

\section{Model 2}

Logarytm ceny hurtowej książki objaśniany zmienną czasową i stawką podatku od towarów i usług na podstawie danych z lat 2003-2012 według metody najmniejszych kwadratów

\begin{tabular}{lcccc} 
& Wspótczynnik & Btad stand. & $t$-Studenta & Wartość $p$ \\
Const & 2,81041 & 0,0158038 & 177,8307 & $<0,00001$ \\
zmienna czasowa & 0,0265306 & 0,0031258 & 8,4876 & 0,00006 \\
stawka podatku & 0,0686505 & 0,0224454 & 3,0586 & 0,01836 \\
Wsp. determ. R-kwadrat & \multicolumn{2}{c}{0,970236} & Skorygowany R-kwadrat & 0,961731 \\
$\mathrm{~F}(2,7)$ & \multicolumn{2}{c}{114,0898} & Wartość p dla testu F & $4,55 \mathrm{e}-06$
\end{tabular}

${ }^{16}$ Oceniając jakość tego modelu, można mieć wątpliwości co do autokorelacji składnika resztowego. Statystyka Durbina-Watsona wynosi 1,49 (z wartościa $p$-value 0,0390281), co sugeruje autokorelację. Inne testy na autokorelację reszt nie potwierdzaja jednak autokorelacji składnika resztowego (statystyka testu LM rzędu $1=0,143816, p$-value 0,718; statystyka testu Ljung-Box Q' $=0,194562, p$-value 0,659; statystyka testu $\mathrm{TR}^{2}=0,234083, p$-value 0,629). Madala (G. S. Maddala, Ekonometria, WN PWN, Warszawa 2008, s. 273) sugeruje, że model wymaga przekształcenia ze względu na niską wartość statystyki Durbina-Watsona tylko wówczas, gdy wartość tej statystyki jest niższa od $\mathrm{R}^{2}$, co nie ma miejsca w analizowanym modelu. 
Podobną analizę do tej przeprowadzonej powyżej można przeprowadzić, przyjmując za zmienną objaśnianą logarytm ceny hurtowej książki. Jeżeli za zmienne objaśniające przyjęte zostaną stawka podatku i inflacja, to istotna będzie tylko ta pierwsza zmienna z $p$-value na poziomie 0,0216 , a inflacja będzie zmienną nieistotna z $p$-value 0,1907 . Model ulega znaczacej poprawie wówczas, gdy inflację $\mathrm{w}$ modelu zastapi zmienna czasowa. W takim modelu obie zmienne objaśniające mogą być uznane za statystycznie istotne, a skorygowany współczynnik determinacji $\mathrm{R}^{2}$ tego modelu wynosi 0,961731 .

Współczynnik przy stawce VAT wynoszacy 0,0686505 można zinterpretować w ten sposób, że zmiana stawki podatku z $0 \%$ na $5 \%$ powoduje wzrost ceny o $7,1 \%{ }^{17}$.

Obserwowane zmiany cen książek, zarówno detalicznych, jak i hurtowych, pozwalają mówić o nadmiernej przerzucalności (overshifting) podatku na konsumentów. Konsekwencją wzrostu ceny jest spadek ilości sprzedanych książek. Potwierdzeniem tej zależności jest model, w którym logarytmiczna zmiana ilości sprzedanych książek to zmienna zależna, a ich logarytmiczna zmiana ceny detalicznej to zmienna objaśniająca. Model ten nawiązuje do cenowej elastyczności popytu, którą ustala się jako procentową zmianę ilości do procentowej zmiany ceny.

\section{Model 3}

Logarytmiczna zmiana ilości sprzedanych książek objaśniana logarytmiczną zmianą ceny detalicznej książki na podstawie danych z lat 2003-2012 według metody najmniejszych kwadratów

$\begin{array}{lcccc} & \text { Wspótczynnik } & \text { Btqd stand. } & \text { t-Studenta } & \text { Wartość } p \\ \text { Const } & 0,06536 & 0,024671 & 2,6492 & 0,03298 \\ \text { logarytmiczna zmiana } & -2,178 & 0,579746 & -3,7568 & 0,00710 \\ \text { ceny detalicznej książki } & & & \\ \text { Wsp. determ. R-kwadrat } & 0,668462 & \text { Skorygowany R-kwadrat } & 0,621099 \\ \text { F(1, 7) } & 14,11370 & \text { Wartość p dla testu F } & 0,007104\end{array}$

Z powyższego modelu wynika, że jeżeli cena wzrośnie o 1\%, to ilość sprzedanych książek spadnie o 2,178\%. Model 3 pozwala wyciagnąć wniosek, że elastyczność cenowa popytu na książki jest wysoka, choć należy zwrócić uwagę na fakt, że w trakcie konstrukcji modelu nie została uwzględniona inflacja.

Dostrzegalny spadek ilości sprzedanych książek zmusza do zastanowienia się nad jego konsekwencjami dla wydawców. Wzrost stawki podatku skutkujący wzrostem ceny i spadkiem ilości sprzedanych książek pozwala posta-

\footnotetext{
17 Oceniając jakość tego modelu, podobnie jak w przypadku modelu 1, można mieć wątpliwości co do autokorelacji składnika resztowego. Statystyka Durbina-Watsona wynosi 1,68 (z wartością $p$-value 0,0843128 ), co sugeruje autokorelację. Inne testy na autokorelację reszt nie potwierdzają jednak autokorelacji składnika resztowego (statystyka testu LM rzędu $1=0,015860$, $p$-value 0,904; statystyka testu Ljung-Box Q' $=0,0269723, p$-value 0,870; statystyka testu $\mathrm{TR}^{2}=$ 0,026363, p-value 0,871). Model nie wymaga przekształcenia ze względu na niską wartość statystyki Durbina-Watsona, ponieważ wartość statystyki DW jest wyższa od $\mathrm{R}^{2}$.
} 
wić pytanie, czy dawcy czynników produkcji (pracy, kapitału) ponoszą ciężar wyższej stawki podatku. Czy w efekcie wyższej stawki podatku stopa zwrotu z kapitału zaangażowanego przez właścicieli wydawnictw maleje, czy wyższa stawka podatku powoduje spadek wynagrodzeń pracowników zatrudnionych przez wydawnictwa?

\section{PRZERZUCALNOŚĆ PODATKU NA WLAŚCICIELI WYDAWNICTW}

O przerzucalności wstecz można mówić wówczas, gdy wzrost stawki podatku powoduje przerzucenie ciężaru podatku na dawców kapitału, dostawców, ale również na pracowników. Analizę konsekwencji wzrostu stawki podatku dla dawców kapitału można rozpocząć od porównania rentowności wydawców w 2010 i 2011 r. W analizie wykorzystane zostały trzy wskaźniki rentowności: wskaźnik rentowności sprzedaży (ROS) liczony jako relacja zysku operacyjnego (EBIT) do przychodów ze sprzedaży; wskaźnik rentowności aktywów ogółem (ROA) liczony jako relacja zysku operacyjnego do aktywów ogółem i wskaźnik rentowności kapitału własnego (ROE) liczony jako relacja zysku operacyjnego do kapitału własnego. W analizie wykorzystane zostały dane ze sprawozdań finansowych przedsiębiorstw, które jako podstawowy zakres działalności deklarowały wydawanie książek (kod NACE Rev.2 5811). Źródłem danych na temat wydawców była baza danych Amadeus. W analizie wzięte pod uwagę zostały wyłącznie te wskaźniki, których poziom był wyższy niż -100\% i niższy niż 100\%. Pozostałe zostały wyeliminowane ze względu na ograniczoną wiarygodność.

Aby ustalić wpływ zmiany stawki podatku na książki na rentowność wydawców, obliczona została ich rentowność w 2010 i 2011 r. i po zestawieniu $\mathrm{w}$ pary przeprowadzony został jednostronny test $t$-Studenta, którego celem była odpowiedź na pytanie, czy rentowność wydawców w roku 2010 jest równa lub niższa niż w 2011. Warunkiem uznania wyników testu za miarodajne jest ustalenie, że spełnione sa warunki do uznania rozkładu analizowanych zmiennych za zgodne z rozkładem normalnym ${ }^{18}$.

Obok testów o różnicy średnich dla dwóch populacji przeprowadzony został test U Manna-Whitneya, nazywany również testem sumy rang Wilcoxona, który jest testem zgodności dwóch rozkładów. Zakłada on, że $\mathrm{F}(\mathrm{x})=\mathrm{G}(\mathrm{x})$ kontra $\mathrm{F}(\mathrm{x})>\mathrm{G}(\mathrm{x})$ dla każdego $\mathrm{x}$. Odrzucenie hipotezy zakładającej zgodność dwóch rozkładów pozwala wyciagnąć wniosek, że mediany dla obu populacji są różne ${ }^{19}$.

${ }^{18} \mathrm{~W}$ badaniach do testowania normalności rozkładu zmiennych stosowane były testy Doornika-Hansena; Shapiro-Wilka, Lillieforsa, Jarque’a-Bera. W analizowanym przypadku żaden z testów nie dał podstaw do odrzucenia hipotezy zerowej, że rozkład zmiennych jest normalny.

${ }_{19}$ Znaczenie tego testu jest szczególne wówczas, gdy nie można stwierdzić, że rozkład porównywanych zmiennych jest rozkładem normalnym. 
Tabela 4

Porównanie wskaźników rentowości wydawców książek w roku 2010 i 2011

\begin{tabular}{|c|c|c|c|c|c|c|c|}
\hline \multirow{2}{*}{ Wskaźnik } & \multirow{2}{*}{$\begin{array}{c}\text { Liczba } \\
\text { wydaw- } \\
\text { nictw }\end{array}$} & \multicolumn{3}{|c|}{ Średnie } & \multicolumn{3}{c|}{ Mediany } \\
\cline { 3 - 8 } & $\mathbf{2 0 1 0}$ & $\mathbf{2 0 1 1}$ & $\boldsymbol{p}$-value & $\mathbf{2 0 1 0}$ & $\mathbf{2 0 1 1}$ & $\boldsymbol{p}$-value \\
\hline ROS & 188 & $5,37 \%$ & $2,73 \%$ & 0,03433 & $4,30 \%$ & $2,35 \%$ & 0,03422 \\
\hline ROA & 200 & $4,29 \%$ & $2,27 \%$ & 0,12105 & $4,44 \%$ & $1,75 \%$ & 0,05219 \\
\hline ROE & 174 & $14,19 \%$ & $7,47 \%$ & 0,00431 & $15,45 \%$ & $5,21 \%$ & 0,00589 \\
\hline
\end{tabular}

Źródło: opracowanie własne na podstawie bazy danych Amadeus.

W powyższym badaniu, przeprowadzonym bez uwzględnienia wskaźników, które były nienaturalnie wysokie (powyżej 100\%) lub niskie (poniżej -100\%), z analizy nie były wykluczone pozostałe wskaźniki dla danego przedsiębiorstwa. Jeżeli jednak dla określonego przedsiębiorstwa brakuje danych pozwalajaccych ustalić wszystkie trzy wskaźniki lub poziom choćby jednego z nich może być uznany za nienaturalny (mało wiarygodny), to wiarygodność wszystkich danych dotyczących danego przedsiębiorstwa może być kwestionowana. W związku z tym przeprowadzona została analiza na podstawie danych zawierających informacje jednocześnie o wszystkich wskaźnikach, spośród których poziom żadnego nie został uznany za nienaturalny (mało wiarygodny).

Tabela 5

Porównanie wskaźników rentowości wydawców książek w roku 2010 i 2011, gdy możliwe było dla danego wydawcy ustalenie wszystkich wskaźników jednocześnie

\begin{tabular}{|c|c|c|c|c|c|c|c|}
\hline \multirow{2}{*}{ Wskaźnik } & \multirow{2}{*}{$\begin{array}{c}\text { Liczba } \\
\text { wydaw- } \\
\text { nictw }\end{array}$} & \multicolumn{3}{|c|}{ Średnie } & \multicolumn{3}{c|}{ Mediany } \\
\cline { 3 - 8 } & $\mathbf{2 0 1 0}$ & $\mathbf{2 0 1 1}$ & $\boldsymbol{p}$-value & $\mathbf{2 0 1 0}$ & $\mathbf{2 0 1 1}$ & $\boldsymbol{p}$-value \\
\hline ROS & 158 & $6,63 \%$ & $2,65 \%$ & 0,00221 & $4,85 \%$ & $2,35 \%$ & 0,00803 \\
\hline ROA & 158 & $7,63 \%$ & $3,65 \%$ & 0,00078 & $5,72 \%$ & $3,50 \%$ & 0,00803 \\
\hline ROE & 158 & $16,21 \%$ & $9,86 \%$ & 0,00950 & $16,11 \%$ & $6,81 \%$ & 0,01127 \\
\hline
\end{tabular}

Źródło: opracowanie własne na podstawie bazy danych Amadeus.

Z porównania poziomu rentowności wydawców w 2010 r., kiedy stawka podatku na książki wynosiła 0\%, z poziomem rentowności w 2011 r., kiedy stawka podatku wynosiła 5\%, wypływa wniosek, że rentowność wydawców spadła w sposób statystycznie istotny. Spośród analizowanych wskaźników z perspektywy właścicieli za najważniejszy może być uznany wskaźnik rentowności kapitału własnego. Wskaźnik ten jest szczególnie ważny, ponieważ informuje o stopie zwrotu z zaangażowanego przez właściciela kapitału. Może on być traktowany jako informacja o poziomie wynagrodzenia czynnika pro- 
dukcji, jakim jest kapitał. W celu wyjaśnienia przyczyn spadku tego wskaźnika przeprowadzona została analiza DuPonta. Do jej przeprowadzenia wykorzystane zostały średnie wartości przychodów ze sprzedaży, aktywów ogółem, kapitału własnego i zysku operacyjnego dla 158 wydawców książek.

Tabela 6

Analiza DuPonta dla wydawców książek w latach 2010-2011

\begin{tabular}{|c|c|c|c|c|}
\hline Rok & $\begin{array}{c}\text { Rentowność } \\
\text { kapitału } \\
\text { własnego (ROE) }\end{array}$ & $\begin{array}{c}\text { Rentowność } \\
\text { sprzedaży (ROS) }\end{array}$ & $\begin{array}{c}\text { Rotacja aktywów } \\
\text { (przychody ze } \\
\text { sprzed./aktywa } \\
\text { ogółem) }\end{array}$ & $\begin{array}{c}\text { Mnożnik } \\
\text { kapitałowy } \\
\text { (aktywa ogółem/ } \\
\text { kapitał własny) }\end{array}$ \\
\hline 2010 & $15,52 \%$ & $8,96 \%$ & $91,91 \%$ & $188,36 \%$ \\
\hline 2011 & $9,94 \%$ & $5,91 \%$ & $87,87 \%$ & $191,24 \%$ \\
\hline
\end{tabular}

Źródło: opracowanie własne na podstawie bazy danych Amadeus.

Na podstawie analizy DuPonta można wyciągnąć wniosek, że obniżenie wskaźnika rentowności kapitału własnego wynika przede wszystkim z obniżenia wskaźnika rentowności sprzedaży. Tylko w tym zakresie miały miejsce znaczące zmiany.

Tabela 7

Porównanie zysku operacyjnego i przychodów ze sprzedaży wydawców książek w roku 2010 i 2011

\begin{tabular}{|c|c|c|c|c|c|c|c|}
\hline \multirow{2}{*}{ Kategoria } & \multirow{2}{*}{$\begin{array}{c}\text { Liczba } \\
\text { wydaw- } \\
\text { nictw }\end{array}$} & \multicolumn{3}{|c|}{ Średnie } & \multicolumn{3}{|c|}{ Mediany } \\
\hline & & 2010 & 2011 & $p$-value & 2010 & 2011 & $p$-value \\
\hline $\begin{array}{l}\text { Zysk } \\
\text { operacyjny }\end{array}$ & 158 & 1613 & 1025 & 0,03558 & 115 & 32 & 0,00208 \\
\hline $\begin{array}{l}\text { Przychody ze } \\
\text { sprzedaży }\end{array}$ & 158 & 17993 & 17337 & 0,04887 & 2976 & 2987 & 0,34224 \\
\hline
\end{tabular}

Źródło: opracowanie własne na podstawie bazy danych Amadeus.

Średnie wartości zysku operacyjnego oraz przychodów ze sprzedaży w 2011 r. w porównaniu z 2010 r. mogą być uznane za niższe przy poziomie istotności wynoszącym 5\%. Na tej podstawie można wyciagnąć wniosek, że obniżenie rentowności sprzedaży wynika zarówno ze spadku przychodów ze sprzedaży, jak i spadku zysku operacyjnego. Należy przy tym podkreślić, że zysk operacyjny to kategoria ściśle związana z przychodami ze sprzedaży. Jeżeli w przedsiębiorstwie występują koszty stałe, a to w przypadku wydawców książek nie powinno budzić wątpliwości, to spadek przychodów ze sprzedaży musi skutkować spadkiem zysku operacyjnego (problem dźwigni operacyjnej). 
Na podstawie przedstawionych powyżej analiz można jednoznacznie stwierdzić, że w 2011 r. w porównaniu z 2010 miał miejsce spadek rentowności kapitału własnego wydawców książek, który wynika ze spadku przychodów ze sprzedaży. Spadek przychodów ze sprzedaży w 2011 r. w porównaniu z 2010 mógł być efektem zmiany stawki podatku, ale mógł być również efektem innych zmian zachodzących na rynku książki. Podstawowy problem na tym etapie polega na weryfikacji hipotezy, że spadek rentowności jest efektem wzrostu stawki podatku, a nie wyłącznie spadku koniunktury na rynku książek.

Na poziom obrotów wydawców książek w Polsce ma wpływ wiele czynników. Część z nich wiąże się z występowaniem pewnych tendencji na rynku książek, część wynika z sytuacji gospodarczej w państwie, w tym ze zmian stawki podatku od towarów i usług. Obroty wydawców książek w roku 2011 w porównaniu z 2010 spadły o 7,8\%. W tym samym czasie obroty europejskich wydawców książek stowarzyszonych w Federation of European Publishers wyrażone w euro spadły o 3,0\%. Wydaje się zatem, że spadek obrotów europejskich wydawców może częściowo wyjaśniać zmiany zachodzące na polskim rynku. Dążąc do wyjaśnienia poziomu obrotów polskich wydawców książek, stworzony został model, w którym za zmienną objaśnianą przyjęty został logarytm obrotów wydawców książek w Polsce, a za zmienne objaśniane logarytm obrotów europejskich wydawców książek (Federation of European Publishers) zmienna czasowa oraz stawka podatku od towarów i usług. Ponieważ w modelu wartość $p$ dla zmiennej objaśniającej dotyczącej obrotów europejskich wydawców wynosiła 0,42603, dlatego w dalszych analizach pominięto tę zmienna, co poprawiło wszystkie 3 kryteria informacyjne modelu (kryterium informacyjne Akaike'a, Bayesowskie kryterium informacyjne Schwartza, kryterium informacyjne Hannana-Quinna). Brak zależności pomiędzy obrotami europejskich i polskich wydawców w latach 2003-2012 spowodował, że za zmienne objaśniające poziom obrotów wydawców książek uznano wyłącznie zmienną czasową i stawkę podatku od towarów i usług, co przedstawia model 4. W takim przypadku jakość modelu mierzona skorygowanym współczynnikiem dopasowania $\mathrm{R}^{2}$ jest wysoka, a obie zmienne objaśniające są istotne statystycznie z wartością $p$ na niskim poziomie.

\section{Model 4}

Logarytm obrotów wydawców książek (wg danych Polskiej Izby Książki, w mln zł), objaśniany zmienną czasową i stawką podatku od towarów i usług na podstawie danych z lat 2003-2012 według metody najmniejszych kwadratów

\begin{tabular}{lcccc} 
& Wspótczynnik & Btad stand. & $t$-Studenta & Wartość $p$ \\
Const & 7,61376 & 0,0303808 & 250,6111 & $<0,00001$ \\
zmienna czasowa & 0,05006 & 0,0060089 & 8,3315 & 0,00007 \\
stawka podatku & $-0,19209$ & 0,0431483 & $-4,4519$ & 0,00296 \\
Wsp. determ. R-kwadrat & \multicolumn{2}{c}{0,912443} & Skorygowany R-kwadrat & 0,887427 \\
$\mathrm{~F}(2,7)$ & \multicolumn{2}{c}{36,47386} & Wartość p dla testu F & 0,000199
\end{tabular}


Współczynnik przy zmiennej dotyczącej stawki podatku wynoszaccy -0,19209 można interpretować w ten sposób, że wzrost stawki podatku z 0\% do 5\% powoduje spadek obrotów wydawców o 17,5\%. Jeśli zatem w efekcie wzrostu podatku o 5 punktów procentowych obroty wydawców spadły o 17,5\%, a z wcześniejszych modeli wiemy, że w efekcie wzrostu stawki wzrosła cena hurtowa o 7,1\%, to można na tej podstawie wyciagnaćc wniosek, że ilość sprzedanych książek spadła o $23 \%$.

W celu potwierdzenia powyższych prawidłowości wykorzystane zostały dane dotyczące wydawców książek znajdujące się w bazie danych Amadeus. W bazie tej znajdują się dane dotyczące 15 polskich wydawnictw, dla których dla okresu 2003-2012 dostępne są informacje dotyczące przychodów ze sprzedaży, aktywów ogółem, kapitału własnego i zysku operacyjnego. Dane te stanowiły podstawę do stworzenia modelu, w którym zmienną zależną był logarytm obrotów tych wydawnictw, a zmiennymi objaśniajacymi, podobnie jak w modelu 4, zmienna czasowa oraz stawka podatku od towarów i usług. Współczynnik przy zmiennej stawka podatku od towarów i usług wynoszacy -0,242304 oznacza, że wzrost stawki z 0\% do 5\% powoduje spadek obrotów wydawców o $21,5 \%$.

\section{Model 5}

Logarytm obrotów wydawców książek (wg danych bazy Amadeus, w tys. zł), objaśniany zmienna czasową i stawką podatku od towarów i usług na podstawie danych z lat 2003-2012 według metody najmniejszych kwadratów

\begin{tabular}{lcccc} 
& Wspótczynnik & Btad stand. & $t$-Studenta & Wartość $p$ \\
Const & 12,971 & 0,0696983 & 186,1018 & $<0,00001$ \\
zmienna czasowa & 0,048516 & 0,0137854 & 3,5193 & 0,00974 \\
stawka podatku & $-0,242304$ & 0,0989891 & $-2,4478$ & 0,04425 \\
Wsp. determ. R-kwadrat & \multicolumn{2}{c}{0,638911} & Skorygowany R-kwadrat & 0,535742 \\
$\mathrm{~F}(2,7)$ & \multicolumn{2}{c}{6,192891} & Wartość p dla testu F & 0,028291
\end{tabular}

Kolejnym sposobem na potwierdzenie zależności pomiędzy obrotami wydawców a stawką podatku od towarów i usług było stworzenie kolejnych modeli ekonometrycznych, tym razem opartych na przyrostach poszczególnych zmiennych. W punkcie wyjścia za zmienną objaśniana przyjęta została zmiana obrotów wydawców ustalona na podstawie danych z Polskiej Izby Książki, a za zmienne objaśniające zmiana obrotów europejskich wydawców, dynamika PKB w Polsce oraz stawka podatku od towarów i usług. Ze względu na niska jakość modeli eliminowane były kolejne nieistotne zmienne objaśniające z najwyższą wartością $p$. Wraz z eliminacją kolejnych zmiennych objaśniających o najwyższej wartości $p$-value poprawiała się jakość modelu mierzona skorygowanym $\mathrm{R}^{2}$. Ostatecznie ustalony został model, w którym jedyna istotną statystycznie zmienną objaśniającą z $p$-value na poziomie 0,09059 jest zmiana stawki podatku od towarów i usług. 


\section{Model 6}

Logarytmiczna zmiana obrotów wydawców książek (wg danych Polskiej Izby Książki) objaśniana zmianą stawki podatku od towarów i usług na podstawie danych z lat 2004-2012 według metody najmniejszych kwadratów

\begin{tabular}{lcccc} 
& Wspótczynnik & Btąd stand. & $t$-Studenta & Wartość $p$ \\
Const & 0,0407969 & 0,0207739 & 1,9639 & 0,09031 \\
zmiana stawki podatku & $-0,122258$ & 0,0623218 & $-1,9617$ & 0,09059 \\
Wsp. determ. R-kwadrat & 0,354740 & Skorygowany R-kwadrat & 0,262560 \\
$\mathrm{~F}(1,7)$ & 3,848347 & \multicolumn{2}{l}{ Wartość p dla testu F } & 0,090590
\end{tabular}

Z trzech powyższych modeli wynika wniosek, że stawka (zmiana stawki) w sposób statystycznie istotny wpływa na obroty wydawców książek (zmianę obrotów wydawców książek).

Na podstawie dotychczasowych analiz można zatem stwierdzić, że wzrost stawki podatku powoduje wzrost ceny detalicznej książek, a to prowadzi do spadku ilości sprzedanych książek. Spadek ilości sprzedanych książek ma wpływ na wynagrodzenie czynnika produkcji, jakim jest kapitał. Oznacza to, że nie tylko konsumenci, lecz także właściciele wydawnictw ponoszą ciężar wyższej stawki podatku na książki.

\section{PRZERZUCALNOŚC PODATKU NA PRACOWNIKÓW}

Kolejnym obok kapitału czynnikiem produkcji zaangażowanym w wydawnictwach jest czynnik pracy. W dalszej części podjęta zostanie próba odpowiedzi na pytanie, czy wzrost stawki podatku miał wpływ na wynagrodzenie pracowników zatrudnionych przez wydawców książek.

W działalności wydawniczej około $75 \%$ osób pracujących to osoby zatrudnione na etacie. Pozostałe $25 \%$ to współpracujacy na podstawie umów zlecenia i umów o dzieło. Wśród nich sa graficy, operatorzy DTP, redaktorzy ${ }^{20}$. Wspomniane proporcje w kolejnych latach ulegały zmianie, choć nieznacznie.

Zgodnie z raportem PIK etatowe zatrudnienie w 2010 r. wynosiło 6230, a w 2011 - 5960, a zatem w tym okresie miał miejsce spadek liczby osób zatrudnionych na etacie o 4,3\%. W dwudziestu wydawnictwach, które ze względu na dostęp do informacji o wysokości wynagrodzeń i liczbie zatrudnionych podlegały szczegółowej analizie, liczba pracowników zatrudnionych na etacie w roku 2010 wynosiła 1229, a w 2011 - 1191. W tym przypadku odnotowano spadek liczby osób na etacie o $3,1 \%$.

Ze względu na brak informacji o liczbie osób współpracujących w ramach umów zleceń i umów o dzieło nie sposób wskazać, czy odnotowany spadek wynikał ze zmiany struktury osób pracujących i współpracujących, czy ze spadku

${ }^{20}$ Badanie rynku książki w Polsce. Raport Polskiej Izby Książki, http://www.pik.org.pl/upload/files/Rynek_ksiazki.Raport_PIK_7-11-2013_final.docx. 
ogólnej liczby pracujących. Warto w tym miejscu podkreślić, że przy ustalaniu przeciętnego wynagrodzenia $\mathrm{w}$ mianowniku brane są pod uwagę wyłącznie osoby pozostające na etacie, natomiast niezależnie od tego, czy ktoś wykonuje swoją prace na etacie, czy w ramach umowy zlecenia lub o dzieło, wszystkie te rodzaje współpracy mają swoje odzwierciedlenie w kosztach wynagrodzeń. Wzrost liczby osób realizujących umowy zlecenia lub o dzieło będzie prowadził do zawyżenia przeciętnego wynagrodzenia.

\section{Tabela 8}

Porównanie przeciętnego miesięcznego wynagrodzenia w wydawnictwach w roku 2010 i 2011

\begin{tabular}{|c|c|c|c|c|c|c|c|}
\hline \multirow{2}{*}{ Kategoria } & \multirow{2}{*}{$\begin{array}{c}\text { Liczba } \\
\text { wydaw- } \\
\text { nictw }\end{array}$} & \multicolumn{3}{|c|}{ Średnie } & \multicolumn{3}{|c|}{ Mediany } \\
\hline & & 2010 & 2011 & $p$-value & 2010 & 2011 & $p$-value \\
\hline $\begin{array}{l}\text { Przeciętne } \\
\text { wynagrodzenie } \\
\text { (w zł) }\end{array}$ & 20 & 9092 & 8767 & 0,24230 & 8951 & 7773 & 0,33258 \\
\hline $\begin{array}{l}\text { Przeciętne } \\
\text { wynagrodzenie } \\
\text { indeksowane } \\
\text { wskaźnikiem } \\
5,4 \% \text { (w zł) }\end{array}$ & 20 & 9092 & 8318 & 0,04486 & 8951 & 7375 & 0,21639 \\
\hline
\end{tabular}

Źródło: opracowanie własne na podstawie bazy danych Amadeus.

Z porównań przeciętnego poziomu wynagrodzeń pracowników zatrudnionych w wydawnictwach wynika, że średnie wynagrodzenie w roku 2011 było niższe niż wynagrodzenie w 2010 . Warto przy tym zauważyć, że przeciętne miesięczne wynagrodzenie w gospodarce narodowej w $2010 \mathrm{r}$. wynosiło 3224,98 zł, a w 2011 - 3399,52 zł, co oznacza wzrost o 5,4\%. Jeżeli zatem uwzględni się zmiany, które $\mathrm{w}$ analizowanym okresie zachodzily $\mathrm{w}$ gospodarce, to przy porównaniu wynagrodzeń z 2010 i 2011 uzasadnione jest zindeksowanie tych ostatnich wskaźnikiem na poziomie $5,4 \%$. W takim przypadku różnica pomiędzy poziomem średniego wynagrodzenia $\mathrm{w}$ obu analizowanych latach będzie jeszcze większa. Wyniki tego porównania zostały zaprezentowane w tabeli 8 . Z tabeli wynika, że różnice zindeksowanych wynagrodzeń oparte o średnie można uznać za istotne statystycznie przy poziomie istotności wynoszacym $5 \%$. Test ten mógłby być uznany za wartościowy, gdyby spełnione było założenie o normalności rozkładu zmiennych. Na podstawie przeprowadzonych testó $w^{21}$ nie można jednak stwierdzić, że zmienna „przeciętne wynagrodzenie” w 2011 r. ma rozkład normalny. W tym przypadku większe znaczenie należałoby przywiązywać do testów U-Manna-Whitneya. Testy te nie daja jednak

${ }^{21}$ Test Doornika-Hansena $=5,70154, \mathrm{z}$ wartościa $p=0,0577997$; test Shapiro-Wilka $=0,903778, \mathrm{z}$ wartościa $p=0,0485698$; test Lillieforsa $=0,186009, \mathrm{z}$ wartością $p=0,07$; test Jarque'a-Bera $=3,66778, \mathrm{z}$ wartością $p=0,159791$. 
podstaw do tego, by stwierdzić, że istnieją statystycznie istotne różnice pomiędzy medianami wynagrodzeń w roku 2010 i 2011.

Pomimo zaobserwowanego spadku wynagrodzeń w roku 2011 w porównaniu z 2010, który mógłby być w rzeczywistości jeszcze większy, gdyby w kosztach wynagrodzeń uwzględnione zostały wyłącznie wynagrodzenia pracowników zatrudnionych na etacie, nie ma statystycznych podstaw do tego, by jednoznacznie stwierdzić, że ciężar podatku od towarów i usług został przerzucony na pracowników.

\section{PRZERZUCALNOŚĆ PODATKU NA DOSTAWCÓW}

Podatek od towarów i usług na książki może mieć również konsekwencje dla dostawców wydawców książek. Najwłaściwszym sposobem analizy przerzucalności podatku wstecz - na dostawców, byłoby odniesienie się do wartości zakupionych przez wydawców książek towarów i usług. Dostęp do tych danych jest jednak ograniczony. W bazie danych, z której korzystał autor, znajduje się wprawdzie pozycja dotycząca wartości zakupionych towarów i usług (costs of goods sold), ale wydawcy książek majacych siedzibę w Polsce informacji tej nie udostępnili. Jednymi z ważniejszych dostawców dla wydawców książek są drukarnie. Badanie przerzucalności wstecz w części dotyczącej dostawców mogłoby zostać zawężone do analizy sytuacji drukarni na przełomie 2010 i 2011 r., gdy zmianie uległa stawka podatku od towarów i usług na książki. Drukarnie według klasyfikacji NACE Rev.2 mają kod 18.1222. Problem polega jednak na tym, że nie zajmują się one wyłącznie drukiem książek, co uniemożliwia wyciaganie wniosków dotyczących przerzucalności podatku od towarów i usług nałożonego na książki na drukarzy.

\section{PODSUMOWANIE}

Podatek od wartości dodanej klasyfikowany jest zazwyczaj jako podatek konsumpcyjny. Podczas analizy mechanizmu tego podatku zakłada się, że jego ciężar ponoszą konsumenci, gdyż to oni płacą ostateczną cenę zawierająca podatek. Konsekwencje wzrostu stawki podatku od towarów i usług sa jednak bardziej złożone. Na podstawie przeprowadzonych analiz dotyczących rynku

${ }^{22}$ Kod NACE Rev2 18.12 obejmuje drukowanie czasopism i pozostałych periodyków wydawanych rzadziej niż cztery razy w tygodniu; drukowanie książek, broszur, nut i manuskryptów, map, atlasów, plakatów, katalogów reklamowych, prospektów i innych reklam, znaczków pocztowych, znaczków skarbowych, druków manipulacyjnych, czeków i innych papierów wartościowych, kart inteligentnych, albumów, kalendarzy, notatników, pamiętników, formularzy, papieru listowego, papieru z nagłówkiem i innych podobnych artykułów drukowanych za pomocą maszyn drukarskich, offsetowych, rotograwiurowych, fleksograficznych, sitodruku i pozostałych maszyn drukarskich, kserokopiarek, drukarek komputerowych, wytłaczarek, fotokopiarek i termokopiarek, włączając szybkie drukowanie; drukowanie bezpośrednio na wyrobach/materiałach tekstylnych, tworzywie sztucznym, szkle, metalu, drewnie i ceramice; drukowanie etykiet i przywieszek. 
książki nie można wyciąnąć wniosku, że podatek od towarów i usług obciążył wyłącznie konsumentów i spowodował wzrost ceny książek proporcjonalny do zmiany stawki podatku.

Przeprowadzone badania pozwalają stwierdzić, że wzrost stawki podatku na książki z $0 \%$ do 5\% spowodował bardziej niż proporcjonalny wzrost ceny książek, co wskazuje na nadprzerzucalność (overshifting) podatku na czytelników. Wnioski dotyczące nadprzerzucalności podatku na konsumentów $\mathrm{w}$ momencie wzrostu stawki podatku są zbieżne $\mathrm{z}$ wnioskami wyciąniętymi na podstawie innych badań empirycznych. Wzrost ceny był zróżnicowany ze względu na segmenty rynku książki. Można przypuszczać, że wydawcy, podwyższając ceny książek, na które popyt jest stosunkowo sztywny (podręczniki i książki fachowe), dążyli do ograniczenia negatywnych konsekwencji zmiany stawki podatku dla wydawnictw. Analiza konsekwencji zmiany stawki podatku od towarów i usług na książki z podziałem na segmenty pozwoliłaby dostarczyć dodatkowych wniosków, ale wymagałaby dodatkowych informacji.

Znacząca podwyżka cen książek doprowadziła do spadku ilości sprzedanych książek, co przełożyło się na funkcjonowanie wydawnictw, w tym na ich rentowność. Istotny statystycznie spadek rentowności kapitałów własnych w wydawnictwach w roku 2011 w porównaniu z 2010, wynikający ze spadku przychodów ze sprzedaży, pozwala stwierdzić, że ciężar wyższej stawki podatku obciążył właścicieli wydawnictw.

Pomimo obserwowanego po wzroście stawki podatku spadku poziomu wynagrodzeń, zarówno w ujęciu nominalnym, jak i realnym, nie ma podstaw, by uznać, że spadek ten jest istotny statystycznie. Na podstawie przeprowadzonych testów nie można jednoznacznie stwierdzić, że ciężar podatku został przerzucony na pracowników.

W literaturze uznaje się, że przerzucalność podatku ma miejsce wówczas, gdy w efekcie nałożenia (zmiany) podatku zmieniają się ceny. Jeżeli bezpośrednią konsekwencją nałożenia (zmiany) podatku jest zmiana ceny dla nabywców lub dostawców, to uznaje się, że doszło do przerzucalności podatku w przód lub wstecz. Konsekwencją zmiany cen są zmiany ilości sprzedawanych, kupowanych towarów i usług. Na przerzucalność podatków nie powinno się patrzeć zatem wyłącznie przez pryzmat zmiany cen. Analiza konsekwencji nałożenia (zmiany) podatków powinna uwzględnić również ilości sprzedawanych, kupowanych towarów i usług, ponieważ zarówno cena, jak i ilość kształtują równowagę na rynku.

Zmiana stawki podatku na książi powoduje zmiany nie tylko cen, lecz także ilości kształtujących równowagę. Konsekwencje zmiany stawki podatku na książki dotykają nie tylko konsumentów, ale również właścicieli wydawnictw. Wprawdzie nie istnieja statystyczne podstawy, by stwierdzić, że zmiana stawki podatku na książki dotknęła również pracowników zatrudnionych w wydawnictwach, ale nie można tego wykluczyć. Skala zmian na rynku pozwala wyciagnąć wniosek, że dodatkowe straty w dobrobycie (excess burden) wywołane wzrostem stawki podatku na książki są duże, choć nie zostały one skwantyfikowane. Tak zwane trójkąty Harbergera stanowiące graficzne odzwierciedlenie tych strat pojawiłyby się na różnych rynkach, a ich rozmiar przekraczałby wielkości wynikające z klasycznej analizy równowagi cząstko- 
wej po wprowadzeniu podatku na określone dobra. Dodatkowe straty w dobrobycie potęguje fakt, że książka jest tzw. dobrem merytorycznym, którego konsumpcja powinna być przez władzę publiczną wspierana.

Zmiana stawki podatku od towarów i usług na książki, która miała miejsce od 1 stycznia 2011 r., nie była suwerenną decyzją władzy publicznej w Polsce, lecz wynikała ze zobowiązań Polski jako członka Unii Europejskiej. Motywacja do zmian nie były ani względy fiskalne, ani chęć realizacji przy wykorzystaniu podatków jakichkolwiek funkcji pozafiskalnych. Zmiana stawki musiała zostać wprowadzona niezależnie od konsekwencji dla rynku książki. Przedstawione w artykule skutki zmian stawki podatku na książki uświadamiaja, że ustawodawca, wprowadzając zmiany podatkowe, istotnie ingeruje w funkcjonowanie rynku i wywołuje konsekwencje nie tylko dla konsumentów. Konsekwencje zmian podatkowych dla innych podmiotów na pierwszy rzut oka nie są oczywiste i dopiero szczegółowa analiza umożliwia ich identyfikację. Próba określenia skutków zmian w prawie podatkowym, i to w ujęciu ex ante, powinna być wpisana $\mathrm{w}$ proces legislacyjny i stanowić integralną część tego procesu.

dr Arkadiusz Bernal

Uniwersytet Ekonomiczny w Poznaniu

arkadiusz.bernal@ue.poznan.pl

\author{
FORWARD AND BACKWARD SHIFTING OF VALUE ADDED TAX \\ IN THE BOOK MARKET IN POLAND
}

Sum mary

The main objective of the article is to answer the question of who (in the short term) bore the value added tax imposed on books. The research was carried out on empirical data relating to the book market in Poland in 2003-2012. An increase in the tax rate on books from $0 \%$ to $5 \%$ resulted in a more than proportional increase in their prices, which indicates a tax overshifting on consumers. The increase in the prices of books led to a decrease in the number of books sold, which resulted in lower profitability of book publishers. A statistically significant decrease in a rate of return on equity of book publishers in 2011 compared to 2010, as a result of a decrease in revenue, leads to the conclusion that the burden of the higher tax rate was born by the owners of publishing houses. Despite the observed decline in the level of wages, both in nominal and real terms, it is not considered statistically significant. Although it is not possible to conclude that the tax burden was borne by employees of book publishers, such possibility cannot be excluded.

The change of the tax rate on books resulted in changes both in prices and the number of books sold. The analysis of the consequences of an imposition (a change) of a tax should not be limited to changes in prices but should also take into account the number of goods and services purchased and sold. This is because the market equilibrium is influenced by both, the price and the quantity. 
Copyright of Journal of Law, Economics and Sociology is the property of Faculty of Law and Administration of Adam Mickiewicz University in Poznan and its content may not be copied or emailed to multiple sites or posted to a listserv without the copyright holder's express written permission. However, users may print, download, or email articles for individual use.

Właścicielem praw autorskich do „Ruchu Prawniczego, Ekonomicznego i Socjologicznego” jest Wydział Prawa i Administracji Uniwersytetu im. Adama Mickiewicza w Poznaniu. Zawartość czasopisma nie może być kopiowana, przesyłana do innych stron internetowych bądź zamieszczana na blogach bez pisemnej zgody wydawcy. Niemniej artykuły można drukować, kopiować lub przesyłać w formie elektronicznej na własny użytek. 